\title{
Salt acclimation of Nodularia spumigena CCY9414 - a cyanobacterium adapted to brackish water
}

\author{
Fred Möke ${ }^{1}$, Norbert Wasmund ${ }^{2}$, Hermann Bauwe ${ }^{1}$, Martin Hagemann $^{1, *}$ \\ ${ }^{1}$ Plant Physiology, Institute of Biosciences, University of Rostock, Albert-Einstein-Str. 3, 18051 Rostock, Germany \\ ${ }^{2}$ Leibniz Institute for Baltic Sea Research, Warnemünde, Seestr. 15, 18119 Rostock, Germany
}

\begin{abstract}
The toxic cyanobacterium Nodularia spumigena regularly forms large surface blooms in the central Baltic Sea. The Baltic Sea is characterized by a salinity gradient. We analyzed the salt acclimation of the strain N. spumigena CCY9414, the only Nodularia strain with a known genome sequence. $N$. spumigena CCY9414 showed a rather low salt tolerance range, displaying a growth optimum at $12.5 \mathrm{~g} \mathrm{NaCl} \mathrm{l}^{-1}$. Sucrose was identified as the major compatible solute. The expression of the sucrose-phosphate synthase gene was salt-stimulated, which indicates that the salt-induced sucrose accumulation could be regulated at the transcriptional level. Potassium ions and glutamate were also accumulated in Nodularia cells, especially at high salinities when sucrose levels were rather low. Our results indicate that $N$. spumigena CCY9414 represents a truly brackish-water-adapted cyanobacterial strain.
\end{abstract}

KEY WORDS: Compatible solute $\cdot$ Glutamate $\cdot$ Potassium $\cdot$ Sucrose Resale or republication not permitted without written consent of the publisher

\section{INTRODUCTION}

Cyanobacteria are the only prokaryotes that use oxygenic photosynthesis for $\mathrm{CO}_{2}$ assimilation. Moreover, many cyanobacteria are also able to perform $\mathrm{N}_{2}$ fixation. The marine diazotrophic cyanobacteria Trichodesmium erythreum (Bergman et al. 2013) and Crocosphaera watsonii (Großkopf \& Laroche 2012) as well as symbiotic species such as Richelia sp. (Foster et al. 2011) and UCYN-A (Thompson et al. 2012) are important primary producers providing organic carbon but also combined nitrogen sources to the marine food chain (e.g. Zehr 2011). However, many cyanobacteria also synthesize bioactive compounds that are toxic to other organisms. Blooms of toxic cyanobacteria have a dramatic impact on the quality of water for drinking or recreation purposes. It has been predicted that harmful cyanobacterial blooms might expand in the future due to global warming (Paerl \& Huisman 2008).

Nodularia spumigena, a toxic filamentous cyanobacterium of the group Nostocales with heterocysts for $\mathrm{N}_{2}$ fixation, regularly forms huge surface blooms in the central Baltic Sea during summer (Wasmund 1997, Stal \& Walsby 2000, Sivonen et al. 2007). Recently, it was shown that blooming $N$. spumigena colonies comprise highly productive microenvironments providing ammonia to the microbial community (Ploug et al. 2011). Baltic Sea Nodularia strains also are known to produce a variety of bioactive compounds, including nodularin. This cyclic peptide has damaging effects on the mammalian liver (Koskenniemi et al. 2007), and several toxic incidents have been described for the Baltic Sea (Wasmund 2002). The genus Nodularia probably comprises different species with diverse ecological specializations (Moffitt et al. 2001, Lyra et al. 2005). Thus, Nodularia species are found in coastal waters of different salinities (e.g. see the comprehensive list of Nodularia isolates by Lyra et al. 2005), in estuaries (Huber 1984), in salt-affected inland waters (Dorador et al. 2008), and rarely in full sea water (33 g sea salts $\mathrm{l}^{-1}$; Pushparaj et al. 1994).

The Baltic Sea is characterized by a steep salinity gradient with seawater-like salinities at the South- 
west connection to the North Sea and almost freshwater conditions in the Northern and Eastern edges (Samuelsson 1996). The distribution of Nodularia spumigena could depend on the external salinity because blooms occur mostly in the central Baltic Sea characterized by brackish waters around 8 practical salinity units (PSU) (Feistel et al. 2010). To adjust the internal osmotic potential to changing salinities, cyanobacteria are known to accumulate specific classes of compatible solutes (Hagemann 2011). Members of the group Nostocales, such as the model strain Anabaena sp. PCC 7119, usually show optimal growth under fresh water conditions and can acclimate to brackish water salinities by the accumulation of sucrose, which is catalyzed by sucrose-phosphate synthase (SPS) (Porchia \& Salerno 1996).

Compared to freshwater Anabaena strains, Nodularia spumigena seems to prefer brackish water conditions. To get deeper insight into the basic saltacclimation strategy of this ecologically important cyanobacterial genus, we aimed to investigate the salt response of $N$. spumigena under defined laboratory conditions. For this purpose, we used the Baltic Sea isolate N. spumigena CCY9414 (hereafter Nodularia CCY9414), taking advantage of its known genome sequence (GenBank accession no. AAVW 00000000; Voß et al. 2013). Genome searches revealed that Nodularia CCY9414 is potentially able to synthesize sucrose as well as trehalose as compatible solutes. Our results suggest that Nodularia CCY9414 is a brackish-water-adapted cyanobacterium because it grew optimally at salinities around $10 \mathrm{~g} \mathrm{NaCl} \mathrm{l}^{-1}$ and accumulated sucrose as the main compatible solute under these conditions.

\section{MATERIALS AND METHODS}

\section{Strain and cultivation}

Nodularia spumigena CCY9414 was obtained from the Culture Collection Yerseke (CCY) at the Netherlands Institute of Sea Research (NIOZ). This Baltic Sea strain was isolated from surface waters of $\sim 9$ PSU east of the island of Bornholm. It was taken into the strain collection in 1994. Since that time, Nodularia CCY9414 has been maintained in ASN III medium (Rippka et al. 1979) with a reduced $\mathrm{NaCl}$ content of $12.5 \mathrm{~g} \mathrm{NaCl} \mathrm{l}^{-1}$. For our experiments, the cultivation was performed in sterile cell culture bottles (Roth) with ASN III medium, which contained different amounts of $\mathrm{NaCl}$ (our standard medium contained $12.5 \mathrm{~g} \mathrm{NaCl}^{-1}$ ) to mimic different salinities. To com- pare nitrate-grown cells with cells grown under $\mathrm{N}_{2}$ fixing conditions, Nodularia CCY9414 was cultivated either in ASN III medium (containing $8.82 \mathrm{mM}$ $\mathrm{NaNO}_{3}$ ) or ASN III medium devoid of nitrate. The cultures were daily mixed and left to grow up to an optical density at $750 \mathrm{~nm}$ (OD750) of 0.2 to 0.3 within 2 wk under a $16 \mathrm{~h}$ light:8 h dark cycle (with light of $40 \mu \mathrm{mol}$ photons $\mathrm{m}^{-2} \mathrm{~s}^{-1}$ ) and a constant temperature of $20^{\circ} \mathrm{C}$ without $\mathrm{CO}_{2}$ enrichment. Fresh cultures were inoculated with $2 \mathrm{ml}$ of cells to $50 \mathrm{ml}$ medium (final OD750 of 0.01 to 0.02 ). After $7 \mathrm{~d}$ of cultivation, cells from defined volumes were harvested by filtration at the middle of the light period.

\section{Dry mass, chlorophyll, sucrose, and $\mathrm{K}^{+}$ determinations}

For the chemical analyses, cells from $10 \mathrm{ml}$ of culture were sampled by filtration through glass fibre filters (Whatman GF/F). To determine the dry mass (DM), the cells were harvested on pre-weighed filters and were dried at $105^{\circ} \mathrm{C}$ overnight. After cooling in a desiccator, the new masses were estimated. The dry masses of cells were corrected for the salt background by subtracting the dry masses of filters through which the same volume of medium of the corresponding salinity was soaked.

For the combined estimation of chlorophyll and compatible solute contents, the filters were immediately frozen in liquid nitrogen and stored at $-80^{\circ} \mathrm{C}$. Pigments and low-molecular-mass compounds were extracted from frozen filters using $80 \%$ acetone (Roth, HPLC grade) at room temperature for $2 \mathrm{~h}$ (Porra et al. 1989). Chlorophyll a content was estimated spectrophotometrically according to Arnon (1949). The acetone extracts were subsequently dried by vacuum centrifugation. The residues were dissolved in defined volumes of water that contained $50 \mu \mathrm{g}$ of sorbitol as an internal standard. Low-molecular mass compounds were quantitatively analyzed by gas chromatography (GC; Hagemann et al. 2008) or high-performance liquid chromatography (HPLC; Hagemann et al. 2005).

The potassium ion content was estimated using flame photometry as described in great detail by Mikkat et al. (2000). Inorganic ions were extracted by boiling the filters with $5 \mathrm{ml}$ of double-distilled water for $10 \mathrm{~min}$. Appropriate dilutions were used for the $\mathrm{K}^{+}$ estimation with a flame photometer (JENWAY, type PFP7, France). All cell $\mathrm{K}^{+}$values were corrected by $\mathrm{K}^{+}$ values from filters, which were treated with the same amount of pure medium of the corresponding salinity. 


\section{Gene expression}

The expression of selected genes was analyzed using reverse transcriptase PCR (RT-PCR). Samples were taken after incubation at different salinities for $6 \mathrm{~h}$ or $7 \mathrm{~d}$. For RNA extraction, $50 \mathrm{ml}$ of cell material was harvested by filtration through glass fibre filters (Whatman GF/F), immediately frozen in liquid nitrogen, and stored at $-80^{\circ} \mathrm{C}$. To improve the RNA-isolation efficiency, filters were suspended in Buffer RAP (Macherey-Nagel) and homogenized in an ice-cooled cell mill (MM400, Retsch) at maximum speed 3 times for $30 \mathrm{~s}$. Then, RNA was isolated using the Total RNA Isolation Kit from Plant (Macherey-Nagel) as described by the supplier. For reverse transcription, $1 \mu \mathrm{g}$ of DNA-free RNA was used to generate cDNA with a RevertAid cDNA synthesis kit (MBI Fermentas) using random hexamers as primers. The cDNA amounts were calibrated according to signals obtained by PCR amplification of the constitutively expressed $r n p B$ gene (ribonuclease $\mathrm{P}, \mathrm{nsp} 30860$ ). The PCR program of the Biometra TPersonal Thermocycler started with an initial DNA denaturation at $94^{\circ} \mathrm{C}$ for $5 \mathrm{~min}$, followed by 30 cycles of denaturation at $94^{\circ} \mathrm{C}$ for $1 \mathrm{~min}$, annealing at $52^{\circ} \mathrm{C}$ for $1 \mathrm{~min}$, and DNA synthesis at $72^{\circ} \mathrm{C}$ for $1 \mathrm{~min}$, and ended with a single final extension at $72^{\circ} \mathrm{C}$ for $5 \mathrm{~min}$. PCR products were separated in $1 \%$ agarose gels and stained with ethidium bromide. The following primers (purchased from Eurofins MWG Operon) were used for the cDNA amplification: constitutive gene $r n p B$ (rnpB_fw: AAC TAT GAC TAC CCG CCA GCC, rnpB_rev: GGC TTT GCC CAA AGC AAA TCG); spsA (sucrose phosphate synthase; nsp8740; spsA_fw: CCC GCA TTA ACT GAG CCA TTT G, spsA_rev: TAA CTC GTC GTT GCG GTA ACT G); sodB (Fe-containing superoxide dismutase B, nsp31650, sodB_fw: GAC TCC TCT AAG GTG GGA ATC, sodB_rev: CCC AGA CAT CCA AGG TTA AG). The gene-specific primers with an annealing temperature of $52^{\circ} \mathrm{C}$ were generated with the program Clone Manager Suite using the nucleotide sequences from the Nodularia CCY9414 genome available under GenBank accession number AOFE00000000. All primers amplified gene-specific internal fragments of $\sim 300 \mathrm{bp}$.

\section{Statistical analysis}

All experiments were repeated at least twice. In each experiment, the measurements were done as triplicates. Mean values and standard deviations from a typical experiment are shown. Statistical tests were performed using the 2-tailed Student's $t$-test (Microsoft Excel 10.0).

\section{RESULTS}

Cultivation of cells in artificial sea water with or without nitrate addition containing different salt $(\mathrm{NaCl})$ concentrations revealed that Nodularia CCY9414 showed a rather narrow range of salt tolerance. It could only grow in the range of 2.5 to $27 \mathrm{~g}$ $\mathrm{NaCl}^{-1}$. Measurements of growth as increase in DM showed an optimum at $12.5 \mathrm{~g} \mathrm{NaCl}^{-1}$ (Fig. 1A). At
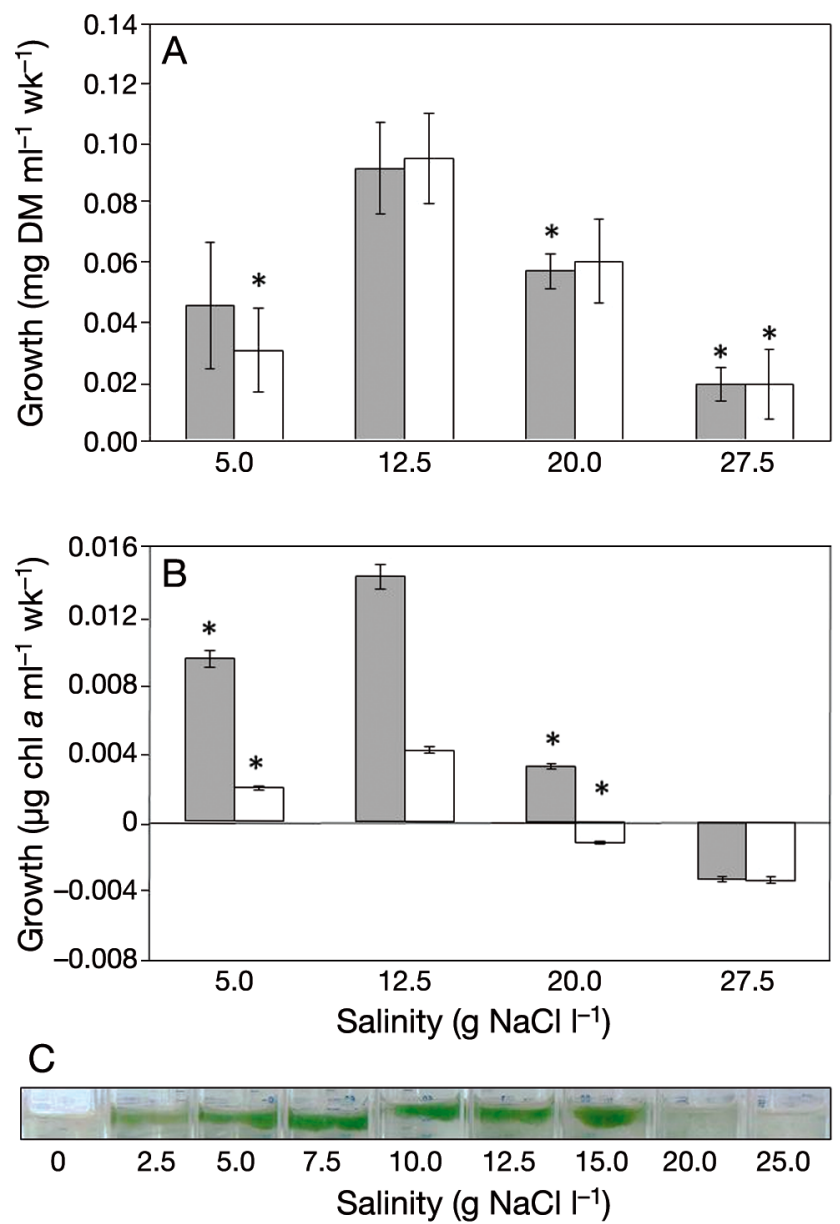

Fig. 1. Growth of Nodularia spumigena CCY9414 at different salinities (in ASN III medium supplemented with $\mathrm{NaCl}$ ) during $7 \mathrm{~d}$ expressed as (A) increase in dry mass (DM) or (B) increase in chlorophyll a ( $\mathrm{chl} \mathrm{a}$ ) content. (C) Appearance of $\mathrm{N}_{2}$-fixing $N$. spumigena CCY9414 cells. Mean values with standard deviations for cells grown without nitrate, i.e. $\mathrm{N}_{2}$ fixing cells, are shown in white columns, while values of nitrate-supplemented cells are presented in grey columns. Values showing statistically significant differences $(p \leq 0.05)$ from the values of cells grown at $12.5 \mathrm{~g} \mathrm{NaCl}^{-1}$ are marked by an asterisk $\left({ }^{*}\right)$ 
salinities $>20 \mathrm{~g} \mathrm{NaCl}^{-1}$, cells of Nodularia CCY9414 grew only very slowly. Moreover, $\mathrm{N}_{2}$-fixing cells showed almost the same salt-dependence of growth as nitrate-grown cells.

A different picture appeared when growth was measured in terms of chlorophyll increase. Nodularia CCY9414 cells transferred to lower or higher salt concentrations showed only small increases in chlorophyll content compared to cells grown at our standard salinity of $12.5 \mathrm{~g} \mathrm{NaCl} \mathrm{l}^{-1}$ (Fig. 1B). Cells transferred to the highest salt level of $27.5 \mathrm{~g} \mathrm{NaCl} \mathrm{l}^{-1}$ even diminished their chlorophyll content in DM. Addition of nitrate clearly supported the chlorophyll production in comparison to $\mathrm{N}_{2}$-fixing cells between 5 and $20 \mathrm{~g} \mathrm{NaCl}^{-1}$. Again, the optimal pigment accumulation was observed under brackish conditions at $12.5 \mathrm{~g} \mathrm{NaCl} \mathrm{l}^{-1}$ (Fig. 1C).

The salt-dependent accumulation of low-molecular mass compounds was analyzed in cells of Nodularia CCY9414 acclimated to different $\mathrm{NaCl}$ amounts for $1 \mathrm{wk}$. GC-analysis was used to detect low-molecular-weight sugars and sugar alcohols. This method revealed only 1 major peak, which was identified as sucrose. Trehalose was never detected in Nodularia CCY9414 cells by our method. The sucrose amount increased with external salinities and showed maximal levels between 12.5 and $15 \mathrm{~g} \mathrm{NaCl} \mathrm{l}^{-1}$ (Fig. 2A) in $\mathrm{N}_{2}$-fixing cells. At the very high salinity of $30 \mathrm{~g} \mathrm{NaCl} \mathrm{l}^{-1}$, it sharply decreased, probably because cells exposed to very high salt concentrations started to lyse. Similar sucrose contents were measured in cells of Nodularia CCY9414 grown with nitrate (Fig. 2B). With this background, all other experiments were carried out with cells grown at only 4 characteristic salinities of $5,12.5,20$, and $27.5 \mathrm{~g} \mathrm{NaCl}^{-1}$.

The expression of the gene for sucrose-phosphate synthase (spsA) was investigated in cells exposed to different salinities by semi-quantitative RT-PCR analysis (Fig. 3). The $r n p B$ gene for the RNA subunit of the ribonucleoprotein RNaseP is known as a constitutive gene that served as a reference of cDNA concentrations. When cells were exposed for $6 \mathrm{~h}$ to different salinities, a stress-proportional increase of spsA mRNA was detected (Fig. 3). However, after salt acclimation for $7 \mathrm{~d}$, the spsA mRNA amount was only slightly higher in cells grown at $12.5 \mathrm{~g} \mathrm{NaCl} \mathrm{l}^{-1}$ than in cells grown in lower salinities, whereas nongrowing cells at very high salinities showed only low sps $A$ expression. Expression of the gene $\operatorname{sodB}$, which is often used as a marker for general or oxidative stress, did not respond to the salt stress treatment of 6 h (Fig. 3).

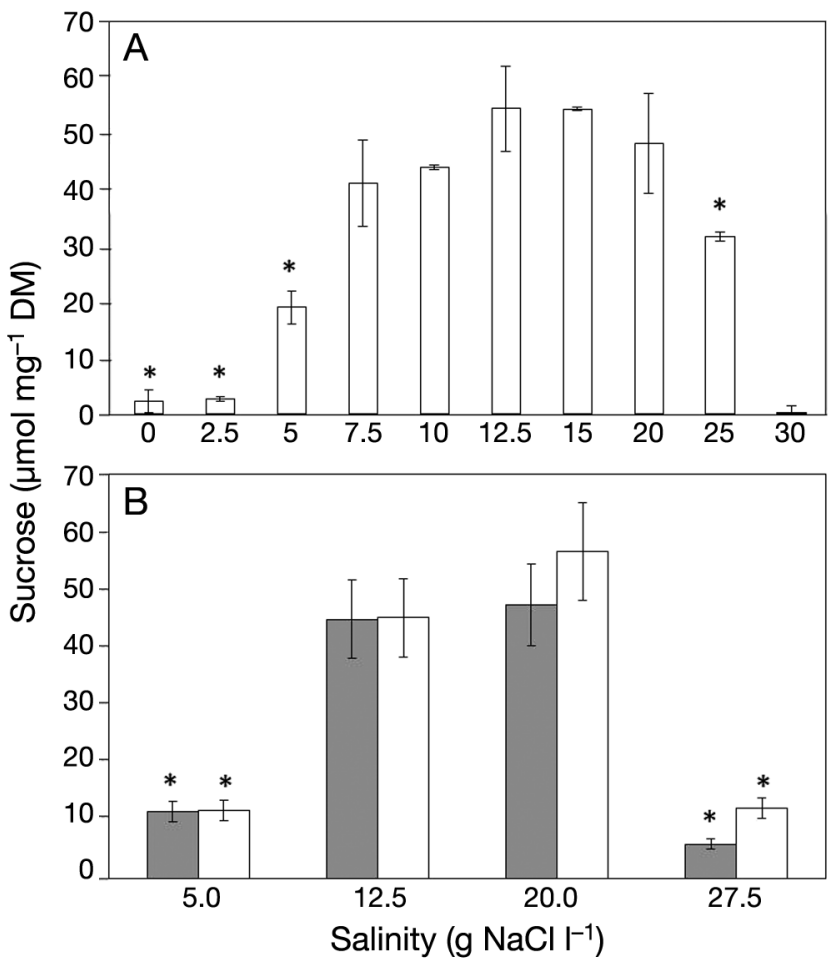

Fig. 2. Accumulation of sucrose as a major compatible solute in Nodularia spumigena CCY9414 at different salinities (in ASN III medium supplemented with $\mathrm{NaCl}$ ) by (A) $\mathrm{N}_{2}$-fixing cells grown under a wide range of salinities and (B) $\mathrm{N}_{2}$-fixing and nitrate-supplemented cells grown side by side at selected salinities. Mean values per dry mass (DM) with standard deviations for cells grown without nitrate, i.e. $\mathrm{N}_{2}$-fixing cells, are shown in white columns, while values of nitratesupplemented cells are presented in grey columns. Values showing statistically significant differences $(p \leq 0.05)$ from the values of cells grown at $12.5 \mathrm{~g} \mathrm{NaCl} \mathrm{l}^{-1}$ are marked by an asterisk $\left({ }^{*}\right)$

Moreover, the contents of soluble amino acids were estimated by HPLC. As usual, glutamic acid was found as the dominating amino acid; it represents almost $50 \%$ of the total pool of soluble amino acids in Nodularia CCY9414. The glutamate amount also showed salt-dependent changes. The highest glutamate levels were observed at the highest salt level of $27.5 \mathrm{~g} \mathrm{NaCl} \mathrm{l}^{-1}$ in both $\mathrm{N}_{2}$-fixing and nitrate-grown cells (Fig. 4A). A slight increase in glutamate was also observed in $\mathrm{N}_{2}$-fixing cells at the lowest salinity of $5 \mathrm{~g} \mathrm{NaCl} \mathrm{l}^{-1}$, whereas the cells cultivated at $12.5 \mathrm{~g}$ $\mathrm{NaCl}^{-1}$ showed the lowest glutamate levels. Finally, we estimated the amount of potassium ions in cells of Nodularia CCY9414. The $\mathrm{K}^{+}$changes at different salinities were similar to the changes in the glutamate levels. The lowest $\mathrm{K}^{+}$levels were detected in cells cultivated in the brackish water conditions, whereas the levels increased to significantly higher amounts in cells exposed to the highest salinity of 


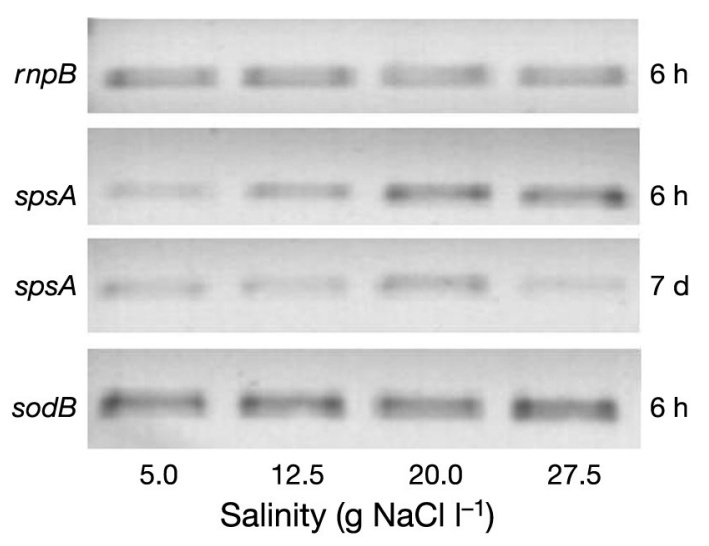

Fig. 3. Expression of stress-regulated genes in Nodularia spumigena CCY9414 at different salinities (in ASN III medium supplemented with $\mathrm{NaCl}$ ), considering $r n p B$ : ribonuclease $\mathrm{P}$, spsA: sucrose phosphate synthase, and sodB: Fe-containing superoxide dismutase B. Total RNA was extracted from cells exposed to different salinities for $6 \mathrm{~h}$ or $7 \mathrm{~d}$. After reverse transcription, the relative amounts of genespecific cDNAs were detected by RT-PCR
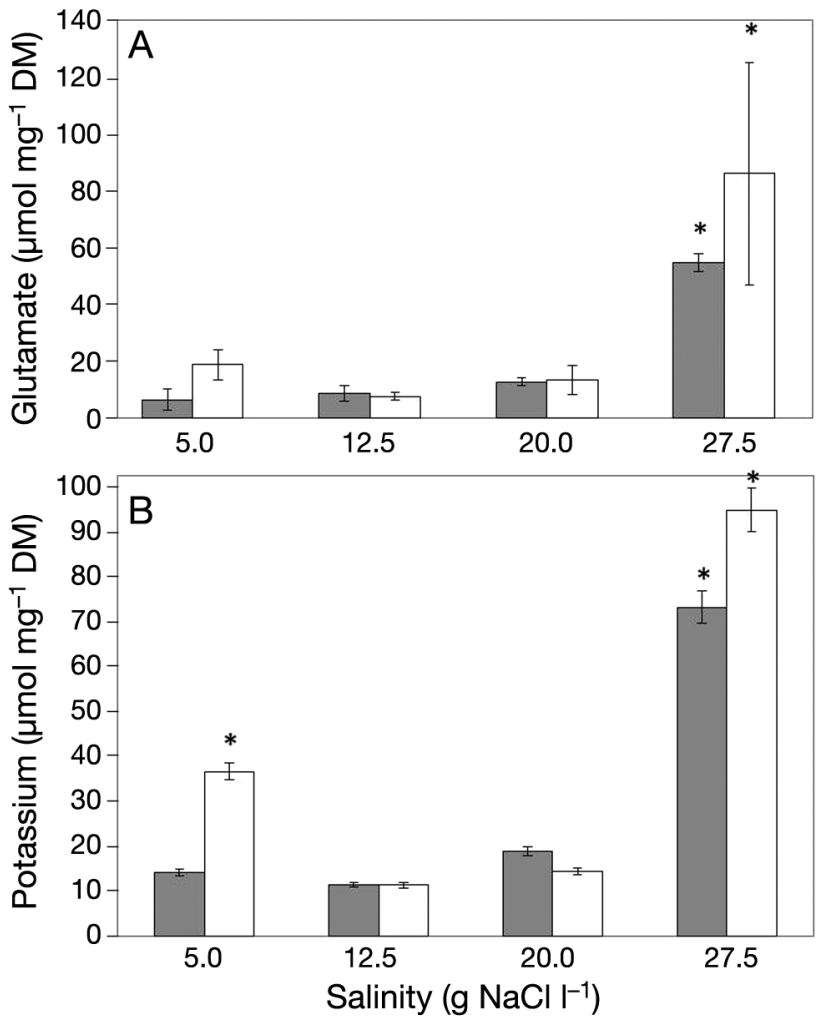

Fig. 4. Accumulation of (A) glutamate and (B) $\mathrm{K}^{+}$in cells of Nodularia spumigena CCY9414 at different salinities (in ASN III medium supplemented with $\mathrm{NaCl}$ ) after $1 \mathrm{wk}$. Mean values with standard deviations for cells grown without nitrate, i.e. $\mathrm{N}_{2}$-fixing cells, are shown in white columns, and those for cells grown with nitrate are presented in grey columns. Values showing statistically significant differences $(\mathrm{p} \leq 0.05)$ to the values of cells grown at $12.5 \mathrm{~g} \mathrm{NaCl} \mathrm{l}^{-1}$ are marked by an asterisk ( $\left.{ }^{*}\right)$. DM: dry mass
$27.5 \mathrm{~g} \mathrm{NaCl}^{-1}$. Under $\mathrm{N}_{2}$-fixing conditions, an increased $\mathrm{K}^{+}$level was also measured at $5 \mathrm{~g} \mathrm{NaCl}^{-1}$ (Fig. 4B). Compared to sucrose, the glutamate and $\mathrm{K}^{+}$ pools were much lower at brackish salinities around $12.5 \mathrm{~g} \mathrm{NaCl} \mathrm{l}^{-1}$ but reached higher levels at the highest salt concentration. Generally, the addition of nitrate to the growth medium did not change the spectrum and the quantities of compatible solutes in Nodularia CCY9414.

\section{DISCUSSION}

Our results support the hypothesis that Nodularia CCY9414 is well adapted to its brackish water environment. As was found for related strains of the Nostocales (Reddy et al. 1989, Fernandes et al. 1993, Moisander et al. 2002), the growth of Nodularia CCY9414 is clearly diminished in media containing more than $20 \mathrm{~g} \mathrm{NaCl} \mathrm{l}^{-1}$. However, in sharp contrast to the studies with freshwater strains of Nostocales that always showed the highest growth rates under $\mathrm{NaCl}$-free conditions, the Baltic Sea isolate Nodularia CCY9414 showed optimal growth after addition of $\sim 10 \mathrm{~g} \mathrm{NaCl}^{-1}$ and decreased rates under low-salt conditions. The brackish water adaptation of Nodularia spumigena is also reflected in its distribution in the natural environment (Fig. 5). In the Baltic Sea, maximal biomass of $N$. spumigena was observed around 7 PSU, and clearly decreased biomass was found at lower as well as higher salinities. Compared to the data of Nodularia abundances in the natural salt gradient of the Baltic Sea, the strain Nodularia CCY9414 showed higher salt tolerance than observed for the natural Baltic Sea Nodularia population. Despite the general difficulties inherent to a comparison of laboratory and field data, this difference could be due to the isolation of a relatively high-

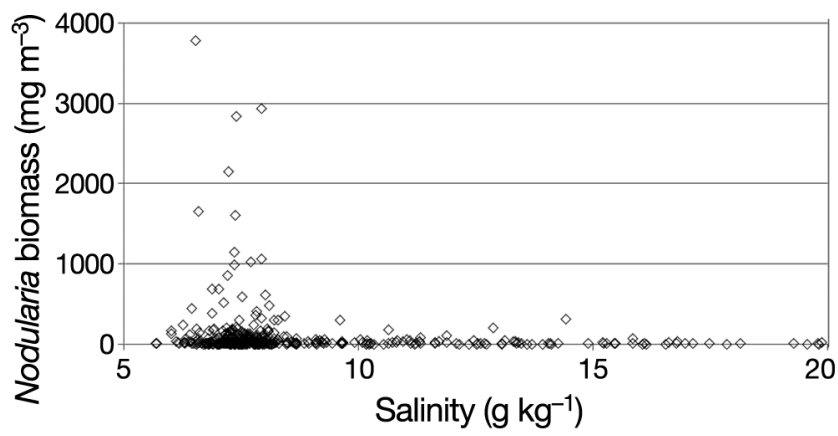

Fig. 5. Nodularia spumigena biomass in the natural salt gradient of the central and western Baltic Sea at 0 to $10 \mathrm{~m}$ depth between 1979 and 2005. Data based on the Baltic Monitoring Program of the Helsinki Commission (HELCOM) 
salt-tolerant ecotype of Nodularia near Bornholm, a part of the Baltic Sea with rather high salinities of 7 to 10 PSU. Moreover, the long-term cultivation of this isolate at $12.5 \mathrm{~g} \mathrm{NaCl} \mathrm{l}^{-1}$ in the stock center CCY might have selected a more salt-tolerant variant of Nodularia.

The salt tolerance range (2 to 25 PSU) of Nodularia CCY9414 correlates well with the accumulation of sucrose as the main compatible solute. Sucrose is also the principal compatible solute in other Nostocales (e.g. Anabaena sp. PCC 7119; Porchia \& Salerno 1996) and has been discussed as the main reason restricting these cyanobacteria to freshwater and brackish water conditions (Hagemann 2011). The genome of Nodularia CCY9414 also harbors genes for the synthesis of trehalose by the TreYZ pathway (Voß et al. 2013). However, we never detected trehalose in cell extracts of salt-treated Nodularia CCY9414. Similarly, the Anabaena sp. PCC 7120 genome also harbors genes for sucrose as well as trehalose synthesis enzymes. In salt-stressed cells of Anabaena sp. PCC 7120, only sucrose is accumulated, whereas trehalose synthesis becomes activated by desiccation stress (Higo et al. 2006).

As expected for a compatible solute, the intracellular concentration of sucrose increased with increasing salt load. However, at very high salinity that did not permit growth of Nodularia CCY9414, the sucrose level decreased again. This effect is probably due to unspecific toxic effects in combination with lysis of cells. The stress-proportional increase of sucrose seems to be at least partly regulated by the expression of sucrose-phosphate synthase SpsA. This enzyme has been shown to be mainly responsible for salt-induced sucrose accumulation in Anabaena sp. PCC 7119 (Porchia \& Salerno 1996). The spsA gene of Nodularia CCY9414 showed a stress-proportional increase in mRNA contents, while the constitutive gene $r n p B$ remained unchanged. We cannot rule out that sucrose synthesis is also salt-stimulated at the enzyme level, as found for enzymes involved in compatible solute synthesis in Synechocystis sp. PCC 6803 (Hagemann \& Marin 1999, Novak et al. 2011). The expression of the sodB gene, encoding the Fecontaining superoxide dismutase induced upon high light, oxidative, and many other stresses (Los et al. 2008), remained unchanged after incubation of Nodularia CCY9414 at different $\mathrm{NaCl}$ concentrations. This finding was unexpected because saltstressed cyanobacterial cells often show to some extent responses to oxidative stress, which is mirrored by increased $s o d B$ transcript levels (e.g. Marin et al. 2004). As a brackish-water-adapted strain,
Nodularia CCY9414 seems to react quite specifically to the salt addition without signs of a general stress situation as indicated by the unchanged $\operatorname{sod} B$ expression.

In addition to sucrose, we found relatively high levels of glutamate and $\mathrm{K}^{+}$in cells of Nodularia CCY9414. Glutamate is often regarded as a minor compatible solute acting as a counter ion for the charged $\mathrm{K}^{+}$. In heterotrophic bacteria such as E. coli, it has been shown that $\mathrm{K}^{+}$and glutamate strongly accumulate after salt shock, but these compounds are replaced by the major compatible solute trehalose during long-term acclimation (Dinnbier et al. 1988). In Nodularia CCY9414, $\mathrm{K}^{+}$and glutamate accumulation was found in osmotically significant amounts, especially under high salt conditions $\left(27.5 \mathrm{~g} \mathrm{NaCl} \mathrm{l}^{-1}\right)$ but also at the lowest salt level of $5 \mathrm{~g}$ $\mathrm{NaCl} \mathrm{l}^{-1}$. At brackish water salt levels (here, $12.5 \mathrm{~g}$

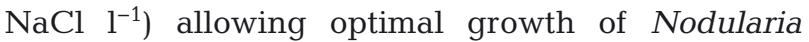
CCY9414, the amount of sucrose exceeded the total amount of $\mathrm{K}^{+}$and glutamate. Possibly, the importance of $\mathrm{K}^{+}$and glutamate is highest at salinities that inhibit growth and probably also photosynthesis, thus limiting the biosynthesis of sucrose. $\mathrm{K}^{+}$accumulation also was found in salt-stressed cells of related Anabaena strains (Apte \& Alahari 1994). Nondiazotrophic oceanic cyanobacteria also accumulate glutamate as a minor compatible solute, but under N-limiting conditions, its amount decreases and it becomes replaced by glucosylglycerate (Klähn et al. 2010). Nodularia CCY9414 is able to fix $\mathrm{N}_{2}$, and the glutamate level remained at similar or even slightly higher levels under diazotrophic growth conditions. Moreover, genes for the alternative glucosylglycerate biosynthesis are absent from its genome, as in other marine $\mathrm{N}_{2}$-fixers (Klähn et al. 2010).

\section{CONCLUSIONS}

Our results indicate that strains of the genus Nodularia are optimally adapted to brackish water conditions. This conclusion is supported by the observation of optimal growth under brackish water conditions regardless of whether the increase in DM or chlorophyll a was used as an indicator. The finding of sucrose as the major compatible solute explains well the usual absence of Nodularia from fully marine conditions. Finally, Nodularia cells cultivated at salinities characteristic of brackish water bodies showed no sign of general stress in terms of low levels of $\mathrm{K}^{+}$and glutamate as well as constitutive levels of $\operatorname{sodB}$ expression. 
Acknowledgements. F.M. was supported by a scholarship from the INF (Interdisziplinäre Fakultät, Maritime Systeme) of the University of Rostock. We thank Prof. L. J. Stal (NIOZ Yerseke, The Netherlands) for providing the Nodularia spumigena CCY9414 culture.

\section{LITERATURE CITED}

> Apte SK, Alahari A (1994) Role of alkali cations $\left(\mathrm{K}^{+}\right.$and $\left.\mathrm{Na}^{+}\right)$ in cyanobacterial nitrogen fixation and adaptation to salinity and osmotic stress. Indian J Biochem Biophys 31: 267-279

> Arnon DI (1949) Copper enzymes in isolated chloroplasts, polyphenoloxidase in Beta vulgaris. Plant Physiol 24:1-15

> Bergman B, Sandh G, Lin S, Larsson J, Carpenter EJ (2013) Trichodesmium - a widespread marine cyanobacterium with unusual nitrogen fixation properties. FEMS Microbiol Rev 37:286-302

> Dinnbier U, Limpinsel E, Schmid R, Bakker EP (1988) Transient accumulation of potassium glutamate and its replacement by trehalose during adaptation of growing cells of Escherichia coli K-12 to elevated sodium chloride concentrations. Arch Microbiol 150:348-357

> Dorador C, Vila I, Imhoff JF, Witzel KP (2008) Cyanobacterial diversity in Salar de Huasco, a high altitude saline wetland in northern Chile: an example of geographical dispersion? FEMS Microbiol Ecol 64:419-432

Feistel R, Weinreben S, Wolf H, Seitz S and others (2010) Density and absolute salinity of the Baltic Sea 20062009. Ocean Sci 6:3-24

Fernandes TA, Iyer V, Apte SK (1993) Differential responses of nitrogen-fixing cyanobacteria to salinity and osmotic stresses. Appl Environ Microbiol 59:899-904

Foster RA, Kuypers MM, Vagner T, Paerl RW, Musat N, Zehr JP (2011) Nitrogen fixation and transfer in open ocean diatom-cyanobacterial symbioses. ISME J 5:1484-1493

Großkopf T, Laroche J (2012) Direct and indirect costs of dinitrogen fixation in Crocosphaera watsonii WH8501 and possible implications for the nitrogen cycle. Front Microbiol 3:236

> Hagemann M (2011) Molecular biology of cyanobacterial salt acclimation. FEMS Microbiol Rev 35:87-123

Hagemann M, Marin K (1999) Salt-induced sucrose accumulation is mediated by sucrose-phosphate-synthase in cyanobacteria. J Plant Physiol 155:424-430

Hagemann M, Vinnemeier J, Oberpichler I, Boldt R, Bauwe $\mathrm{H}$ (2005) The glycine decarboxylase complex is not essential for the cyanobacterium Synechocystis sp. strain PCC 6803. Plant Biol 7:15-22

> Hagemann M, Ribbeck-Busch K, Klähn S, Hasse D, Steinbruch R, Berg G (2008) The plant-associated bacterium Stenotrophomonas rhizophila expresses a new enzyme for the synthesis of the compatible solute glucosylglycerol. J Bacteriol 190:5898-5906

> Higo A, Katoh H, Ohmori K, Ikeuchi M, Ohmori M (2006) The role of a gene cluster for trehalose metabolism in dehydration tolerance of the filamentous cyanobacterium Anabaena sp. PCC 7120. Microbiology 152:979-987

> Huber AL (1984) Nodularia (Cyanobacteriaceae) akinetes in the sediments of the Peel-Harvey Estuary, Western Australia: potential inoculum source for Nodularia blooms. Appl Environ Microbiol 47:234-238

Klähn S, Steglich C, Hess WR, Hagemann M (2010) Glucosylglycerate: a secondary compatible solute common to marine cyanobacteria from nitrogen-poor environments. Environ Microbiol 12:83-94

Koskenniemi K, Lyra C, Rajaniemi-Wacklin P, Jokela J, Sivonen K (2007) Quantitative real-time PCR detection of toxic Nodularia cyanobacteria in the Baltic Sea. Appl Environ Microbiol 73:2173-2179

Los DA, Suzuki I, Zinchenko VV, Murata N (2008) Stress responses in Synechocystis: regulated genes and regulatory systems. In: Herrero A, Flores E (eds) The cyanobacteria - molecular biology, genomics and evolution. Caister Academic Press, Norfolk, p 117-158

> Lyra C, Laamanen M, Lehtimäki JM, Surakka A, Sivonen K (2005) Benthic cyanobacteria of the genus Nodularia are non-toxic, without gas vacuoles, able to glide and genetically more diverse than planktonic Nodularia. Int J Syst Evol Microbiol 55:555-568

> Marin K, Kanesaki Y, Los DA, Murata N, Suzuki I, Hagemann M (2004) Gene expression profiling reflects physiological processes in salt acclimation of Synechocystis sp. strain PCC 6803. Plant Physiol 136:3290-3300

Mikkat S, Milkowski C, Hagemann M (2000) The gene sll0273 of the cyanobacterium Synechocystis sp. strain PCC 6803 encodes a protein essential for growth at low $\mathrm{Na}^{+} / \mathrm{K}^{+}$ratios. Plant Cell Environ 23:549-559

> Moffitt MC, Blackburn SI, Neilan BA (2001) rRNA sequences reflect the ecophysiology and define the toxic cyanobacteria of the genus Nodularia. Int J Syst Evol Microbiol 51:505-512

Moisander PH, McClinton E III, Paerl HW (2002) Salinity effects on growth, photosynthetic parameters, and nitrogenase activity in estuarine planktonic cyanobacteria. Microb Ecol 43:432-442

> Novak JF, Stirnberg M, Roenneke B, Marin K (2011) A novel mechanism of osmosensing, a salt-dependent protein-nucleic acid interaction in the cyanobacterium Synechocystis species PCC 6803. J Biol Chem 286: 3235-3241

> Paerl HW, Huisman J (2008) Blooms like it hot. Science 320: 57-58

> Ploug H, Adam B, Musat N, Kalvelage T, Lavik G, WolfGladrow D, Kuypers MM (2011) Carbon, nitrogen and $\mathrm{O}_{2}$ fluxes associated with the cyanobacterium Nodularia spumigena in the Baltic Sea. ISME J 5:1549-1558

Porchia AC, Salerno GL (1996) Sucrose biosynthesis in a prokaryotic organism: presence of two sucrose-phosphate synthases in Anabaena with remarkable differences compared with the plant enzymes. Proc Natl Acad Sci USA 93:13600-13604

Porra RJ, Thompson WA, Kriedemann PE (1989) Determination of accurate extinction coefficients and simultaneous equations for assaying chlorophylls $a$ and $b$ extracted with four different solvents: verification of the concentration of chlorophyll standards by atomic absorption spectrometry. Biochim Biophys Acta 975:384-394

> Pushparaj B, Pelosi E, Torzillo G, Carlozzi P, Sacchi A, Materassi R (1994) Growth physiology of a marine nitrogenfixing cyanobacterium (Nodularia harveyana) in outdoor culture. J Appl Phycol 6:533-537

Reddy BR, Apte SK, Thomas J (1989) Enhancement of cyanobacterial salt tolerance by combined nitrogen. Plant Physiol 89:204-210

Rippka R, Deruelles J, Waterbury JB, Herdman M, Stanier RY (1979) Generic assignments, strain histories and properties of pure cultures of cyanobacteria. J Gen Microbiol 111:1-61 
Samuelsson M (1996) Interannual salinity variations in the Baltic Sea during the period 1954-1990. Cont Shelf Res 16:1463-1477

Sivonen K, Halinen K, Sihvonen LM, Koskenniemi K and others (2007) Bacterial diversity and function in the Baltic Sea with an emphasis on cyanobacteria. Ambio 36: 180-185

Stal LJ, Walsby AE (2000) Photosynthesis and nitrogen fixation in a cyanobacterial bloom in the Baltic Sea. Eur J Phycol 35:97-108

Thompson AW, Foster RA, Krupke A, Carter BJ and others (2012) Unicellular cyanobacterium symbiotic with a single-celled eukaryotic alga. Science 337: 1546-1550

Editorial responsibility: Douglas Capone

Los Angeles, California, USA
Voß B, Bolhuis H, Fewer DP, Kopf M and others (2013) Insights into the physiology and ecology of the brackishwater-adapted cyanobacterium Nodularia spumigena CCY9414 based on a genome-transcriptome analysis. PLoS ONE 8:e60224

Wasmund N (1997) Occurrence of cyanobacterial blooms in the Baltic Sea in relation to environmental conditions. Int Rev Gesamten Hydrobiol 82:169-184

Wasmund N (2002) Harmful algal blooms in coastal waters of the south-eastern Baltic Sea. In: Schernewski G, Schiewer U (eds) Baltic coastal ecosystems. Springer, Berlin, p 93-116

Zehr JP (2011) Nitrogen fixation by marine cyanobacteria. Trends Microbiol 19:162-173

Submitted: January 24, 2013; Accepted: July 25, 2013

Proofs received from author(s): September 4, 2013 